\title{
Analysis of coupled and decoupled PWM techniques for induction motor drive
}

\author{
Syed. Munvar Ali ${ }^{1}$, V. Vijaya kumar Reddy ${ }^{2}$, M. Surya Kalavathi ${ }^{3}$ \\ ${ }^{1,2}$ Department of Electrical and Electronics engineering, N B K RInstitute of Science and Technology, India \\ ${ }^{3}$ Department of EEE, JNTUH College of Engineering Hyderabad, India
}

\begin{tabular}{l} 
Article Info \\
\hline Article historys: \\
Received Jun 10, 2018 \\
Revised Dec 20, 2018 \\
Accepted Feb 25, 2019 \\
\hline
\end{tabular}

\section{Keywords:}

Coupled PWM

Decoupled PWM

Open end winding induction

motor

Copyright $(2019$ Institute of Advanced Engineering and Science. All rights reserved.

\section{Corresponding Author:}

Syed. Munvar Ali,

Department of Electrical and Electronics engineering,

N B K RInstitute of Science and Technology,

Vidya Nagar, Andhra Pradesh, India.

Email: syedmunvarali@gmail.com

\section{INTRODUCTION}

Multilevel inverter fed induction motor drives are popular for hybrid electric vehicles and ship propulsion applications [1]-[6]. Different multilevel inverter topologies like diode clamped inverter, cascaded $\mathrm{H}$-bridge inverter and dual inverter configuration with different configurations were identified for induction motor. Among multilevel inverter configurations dual inverter configuration [7] is very simple in construction and require a smaller number of semiconductor devices. Moreover, the dual inverters are operated from the isolated individual DC sources which are readily available in electric vehicles and ship propulsion applications.

Different PWM techniques [8]-[11] are employed for inverters for varying output voltage and frequency. Among different PWM techniques space vector based PWM techniques [12], [13] are popular because of providing freedom in selecting voltage vectors. The dual inverter configuration is derived by combining 2 two-level inverters and they are connected in an isolated fashion. Because of presence of two 2level inverters, the PWM techniques can be derived either by treating both the inverters as a single unit or each independently as a separate unit. Based on this the PWM techniques for dual inverters are classified as coupled and decoupled PWM techniques. Both the coupled and decoupled PWM techniques can be implemented by space vector approach. In this paper comparative analysis of coupled and decupled PWM techniques were presented for dual inverter configuration.

In hybrid electric vehicles and ship propulsion applications fast, transient response is required for the drives. Hence the drives are employed with vector or direct torque control techniques [14]-[20]. In both the techniques torque and flux are independently controlled as of a DC motor. Comparing the direct torque control with vector control technique the later gives less ripple in steady state. Therefore, this paper is focussed on vector controlled dual inverter fed induction motor drives. Moreover, the performance of coupled and decupled 
PWM techniques for dual inverter fed open end winding induction motor drive were evaluated in vectorcontrolled environment.

\section{VECTOR CONTROLLED DUAL INVERTER FED OPEN END WINDING INDUCTION MOTOR}

The block diagram of vector controlled open end winding induction motor drive is shown in Figure 1. Both the dual inverters are connected in an isolated fashion with an isolated DC voltage of each $V_{\mathrm{dc}} / 2$ to form the resultant $\mathrm{DC}$ voltage of $\mathrm{V}_{\mathrm{dc}}$. As both the $\mathrm{DC}$ voltage sources are isolated circulating current between the converters will be absent. ao, bo, co and a'o', b'o', c'o' are the pole voltages of inverter-I and inverter-II respectively and they give the resultant phase voltages as aa', bb', cc' and the voltage across the potential OO' is called CMV. Depending up on the switching action each inverter gives a pole voltage of half the DC voltage and 0 volts. When the independent pole voltages of both the inverters are considered as single unit for dual inverter fed open end winding induction motor drive, they result in three level pole voltages as ' $+\mathrm{V}_{\mathrm{dc}} / 2$ ', ' 0 ' and ' $-\mathrm{V}_{\mathrm{dc}} / 2$ '.

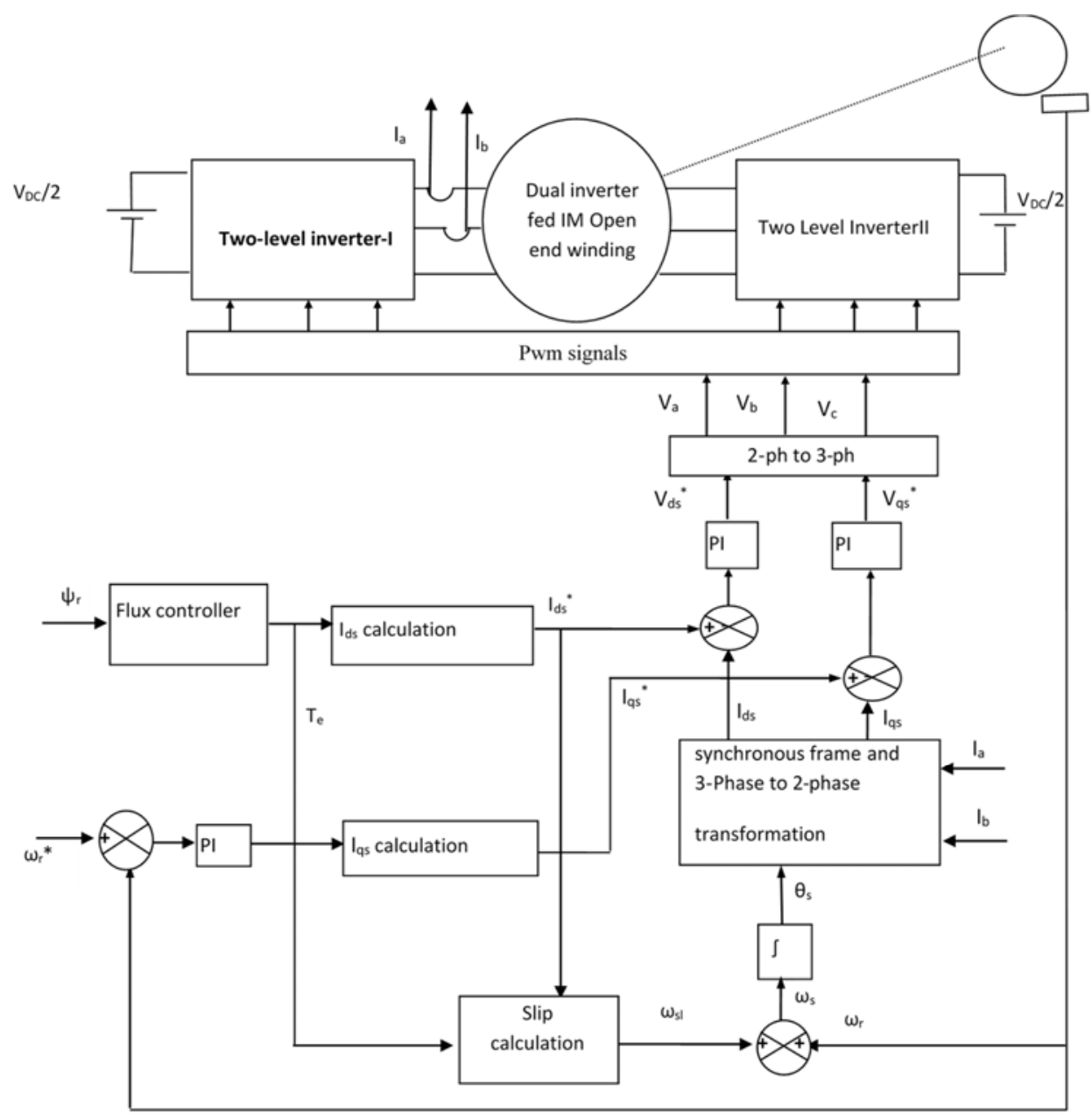

Figure. 1 Vector controlled dual induction motor drive

In vector control algorithm to obtain fast transient response stator current vector $\mathrm{I}_{\mathrm{s}}$ is resolved into $\mathrm{I}_{\mathrm{ds}}$ and $\mathrm{I}_{\mathrm{qs}}$. These quantities $\left(\mathrm{I}_{\mathrm{ds}}\right.$ and $\left.\mathrm{I}_{\mathrm{qs}}\right)$ are to be transferred to synchronous reference frame where they appear as DC quantities. To have reference frame transformation angle $\theta$ s should be estimated. Based on this estimation vector control algorithm is divided into direct vector control and indirect vector control. In the present indirect vector control method $\theta \mathrm{s}$ is estimated as given by (1).

Indo. J. Elec. Eng. \& Inf, Vol. 7, No. 1, March 2019: 95 - 104 


$$
\theta_{s}=\theta_{r}+\theta_{s l}=\int\left(\omega_{r}+\omega_{s l}\right) d t=\int \omega_{s}
$$

where $\omega_{r}$ and $\omega_{s l}$ are rotor speed and slip speed respectively and slip speed is given by (2)

$$
\omega_{s l}=\frac{L_{m} R_{r}}{L_{r} \lambda_{r}} i_{q s}
$$

The general torque expression for induction motor in two quadrant system can be represented as given (3)

$$
T=\frac{3}{2} \frac{P}{2} \frac{L_{m}}{L_{r}}\left(\psi_{d r} i_{q s}-\psi_{q r} i_{d s}\right)
$$

Where $\mathrm{I}_{\mathrm{qs}}$ and $\mathrm{I}_{\mathrm{ds}}$ are stator $\mathrm{q}$-axis and $\mathrm{d}$-axis current components and $\psi_{\mathrm{qr}}$ and $\psi_{\mathrm{dr}}$ are $\mathrm{q}$-axis and daxis rotor flux. The rotor q-axis flux is assumed to be zero $\left(\psi_{\mathrm{qr}}=0\right)$ because the rotor flux is assumed to be aligned to synchronous reference frame. Therefore, the torque magnitude will be changed as given in (4). Hence torque and flux are controlled by $\mathrm{I}_{\mathrm{qs}}$ and $\mathrm{I}_{\mathrm{ds}}$ respectively.

$$
\begin{gathered}
T=\frac{3}{2} \frac{P}{2} \frac{L_{m}}{L_{r}}\left(\psi_{r} i_{q s}\right) \\
\text { where } \psi_{r}=L_{m} I_{d s}
\end{gathered}
$$

From the desired speed and flux reference quantities $\mathrm{I}_{\mathrm{ds}}{ }_{\mathrm{s}}$ and $\mathrm{I}_{\mathrm{qs}}{ }_{\mathrm{s}}$ are derived and they need to be compared with actual $\mathrm{I}_{\mathrm{ds}}$ and $\mathrm{I}_{\mathrm{qs}}$. From the error signals reference $\mathrm{V}_{\mathrm{ds}}$ and $\mathrm{V}_{\mathrm{qs}}$ quantities are obtained and fed to PWM block, by which different PWM techniques will be derived.

\section{PWM TECHNIQUES FOR DUAL INVERTER CONFIGURATION}

For the control of output voltage and frequency pulse width modulation techniques are employed for dual inverter fed open end winding induction motor drive. Based on controlling the inverters in dual inverter configuration, pulse width modulation techniques are classified as coupled and decoupled PWM techniques. Both these PWM techniques can be implemented in digital space vector approach or carrier comparison approach. The difference between both the PWM techniques is that in decoupled PWM techniques both the inverters are treated separately and controlled independently, but in coupled PWM techniques both the inverters are treated as a single unit.

\subsection{Decoupled PWM techniques}

In space vector based decoupled PWM technique for dual inverter 64 switching states are generated giving 3-level output voltage. These 64 switching states are collectively derived from 8 switching states of each inverter. Each individual inverter has 8 switching states which can be independently controlled and the space vector diagram is shown in Figure 2. The switching states of inverter-I and inverter-II synthesizes a reference voltages of magnitude $\mathrm{OA}\left(\mathrm{V}_{\mathrm{Ref1}}\right)$ and $\mathrm{O}^{\prime} \mathrm{A}^{\prime}\left(\mathrm{V}_{\mathrm{Ref} 2}\right)$ instantaneously with the nearest vectors in all the six sectors. Using these individual two-level reference voltage vectors the three-level reference voltage vector can be expressed as in (5).

$$
\mathrm{V}_{\mathrm{Ref}}=\mathrm{V}_{\mathrm{Ref} 1}-\mathrm{V}_{\mathrm{Ref} 2}
$$
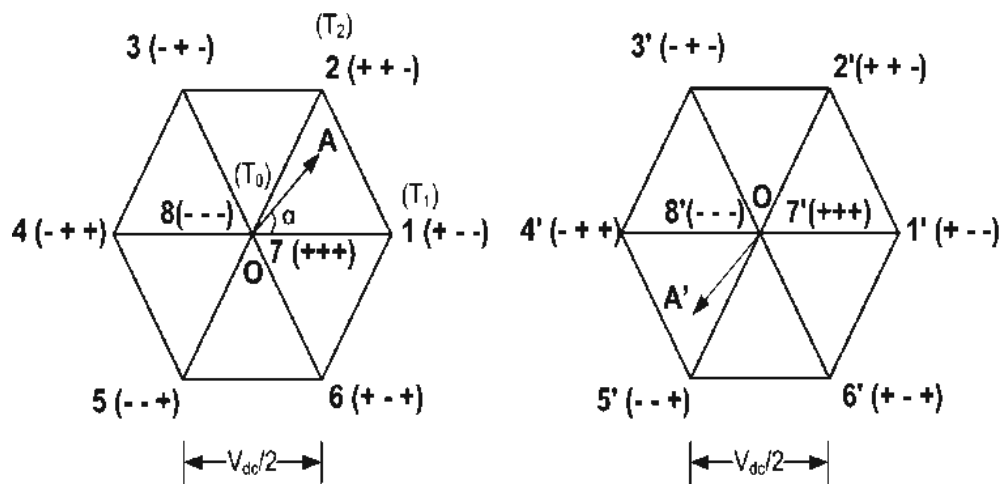

Figure 2. Switching states and their space vector locations of inverter-I and inverter-II.

Analysis of coupled and decoupled PWM techniques for induction motor drive (Syed. Munvar Ali) 
If both inverters are operated with same switching states then the resultant reference voltage vector magnitude will be zero. Hence both inverters should be operated with different switching states. In order to get maximum output voltage there should be an angular displacement of $\pi$ between reference voltage vectors OA $\left(\mathrm{V}_{\text {Ref1 }}\right)$ and $\mathrm{O}^{\prime} \mathrm{A}^{\prime}\left(\mathrm{V}_{\mathrm{Ref} 2}\right)$. Hence reference $\mathrm{OA}\left(\mathrm{V}_{\mathrm{Ref1}}\right)$ should be sampled with nearest voltage vectors in sector 1 and $\mathrm{O}^{\prime} \mathrm{A}^{\prime}\left(\mathrm{V}_{\mathrm{Ref} 2}\right)$ should be sampled with nearest voltage vectors in sector 4 . To satisfy the condition the reference vector should be chosen with phase shift of $\pi$ as given in (6) and (7).

$$
\begin{aligned}
& \mathrm{V}_{\text {ref } 1}=\mathrm{V}_{\mathrm{a}}+\mathrm{V}_{\mathrm{b}} \mathrm{e}^{\mathrm{j} 2 \pi / 3}+\mathrm{V}_{\mathrm{c}} \mathrm{e}^{\mathrm{j} 4 \pi / 3} \\
& \mathrm{~V}_{\mathrm{a}}=\cos (\omega \mathrm{t}) ; \mathrm{V}_{\mathrm{b}}=\cos (\omega \mathrm{t}-120) ; \mathrm{V}_{\mathrm{c}}=\cos (\omega \mathrm{t}-240) \\
& \mathrm{V}_{\text {ref } 2}=\mathrm{V}_{\mathrm{a}^{\prime}}+\mathrm{V}_{\mathrm{b}^{\prime}} \mathrm{e}^{\mathrm{j} 2 \pi / 3}+\mathrm{V}_{\mathrm{c}^{\prime}} \mathrm{e}^{\mathrm{j} 4 \pi / 3} \\
& \mathrm{~V}_{\mathrm{a}^{\prime}}=\cos (\omega \mathrm{t}-180) ; \mathrm{V}_{\mathrm{b}^{\prime}}=\cos (\omega \mathrm{t}-300) ; \mathrm{V}_{\mathrm{c}^{\prime}}=\cos (\omega \mathrm{t}-60) \\
& T_{1}=\frac{T_{s}}{V_{d c}}\left(V_{\text {max }}-V_{\text {mid }}\right) \\
& T_{2}=\frac{T_{s}}{V_{d c}}\left(V_{\text {mid }}-V_{\text {min }}\right) \\
& T_{0}=T_{s}-T_{1}-T_{2}
\end{aligned}
$$

With reference voltage as in (6) and (7), the reference voltage vectors lie in sects-I and sector 4 of the space vector planes as in Figure 3. To get the maximum output voltage and less voltage ripple the nearest switching states are to be selected by volt-sec balance condition. The switching states to be operated for inverter-I and inverter-II to get maximum output voltage are given in Table 1. The corresponding switching times are given (8). The corresponding switching states and switching times at one sampling interval is given in Figure 3. Here T1 and T2 are the active vector times and T0 is the zero state times. The zero-state time is equally shared between both the zero voltage vectors (V7 and V8). Vmax and Vmin are high and low values of the reference signals given in (6) and (7) of first and second inverters.

Table 1. Switching states of inverter-I and inverter-II in all the sectors

\begin{tabular}{cccc}
\hline Sector & $\begin{array}{c}\text { inverter-I Switching } \\
\text { states }\end{array}$ & Sector & $\begin{array}{c}\text { inverter-II Switching } \\
\text { states }\end{array}$ \\
\hline 1 & $8127-7218$ & 4 & $8547-7458$ \\
2 & $8327-7238$ & 5 & $8567-7658$ \\
3 & $8347-7438$ & 6 & $8167-7618$ \\
4 & $8547-7458$ & 1 & $8127-7218$ \\
5 & $8567-7658$ & 2 & $8327-7238$ \\
6 & $8167-7618$ & 3 & $8347-7438$ \\
\hline
\end{tabular}

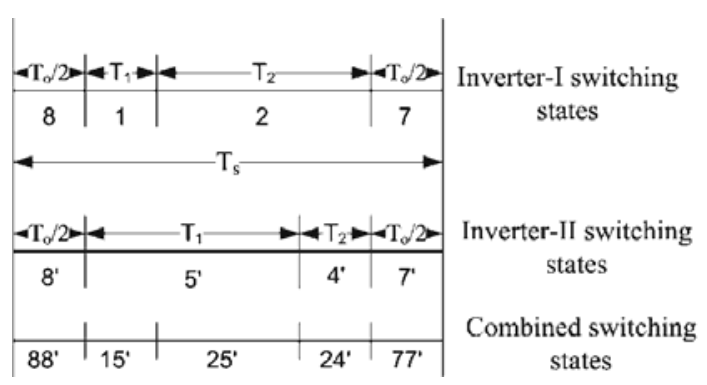

Figure 3. Time slots of the two inverters switching states in one sampling interval.

\subsection{Coupled PWM techniques}

In coupled PWM technique the voltage space vectors of both the inverters are treated as one and there are 19 voltage vectors and 27 switching states as shown in in space vector based decoupled PWM technique for dual inverter a total of 64 switching states Figure 4. As the individual inverters are coupled the PWM inverter gives 3-level output voltage, where as in conventional decoupled PWM inverters the individual inverters are separately synthesized, each having 8 switching vectors and combinely give 64 switching vectors. Therefore, 
coupled PWM technique has a smaller number of switching vectors than decoupled one. The analyzation of the $\mathrm{V}_{\mathrm{Ref}}$ falling in any sector of the space vector hexagon is done by the following conventional algorithm. Its features are (i) The starting and ending switching vector should be same. (ii) During the transition there should change only one switching state. From Figure 4 the space vector hexagon is classified into one inner sub hexagon $\mathrm{H}_{0}$ and six outer sub hexagons $\mathrm{H}_{1}, \mathrm{H}_{2} \ldots \ldots, \mathrm{H}_{6}$ with centres as voltage vectors $\mathrm{V}_{0}$ for $\mathrm{H}_{0}$ and $\mathrm{V}_{7}, \mathrm{~V} 8 \ldots \ldots ., \mathrm{V}_{12}$ for $\mathrm{H}_{1}, \mathrm{H}_{2} \ldots \ldots, \mathrm{H}_{6}$ respectively.

In the present discussion of coupled PWM technique the $V_{\text {Ref }}$ may fall in any one of the 7 sub hexagons. If $\mathrm{V}_{\mathrm{Ref}}$ is in inner sub hexagon $\mathrm{H}_{0}$, it will be synthesized normally $\mathrm{b}$ using nearest voltage vectors. Otherwise if $V_{\text {Ref }}$ present in outer sub hexagons the synthesis is as follows. Assume that $V_{\text {Ref }}$ present in sector1 of $\mathrm{H}_{1}$. From the d-axis and -axis components of $\mathrm{V}_{\mathrm{Ref}}$ the sub hexagon is identified using (9). After identifying the sub hexagon, the tail of $V_{\operatorname{Ref}} V_{0}$ is shifted to $V_{7}$. The new reference vector is given by (10). By using the ' $\alpha$ '

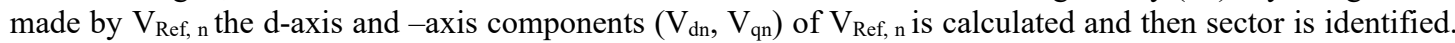
Once sector and sub hexagon are identified the switching states to synthesize the $V_{\text {Ref }}$ to give any phase output voltage in one switching period is given in Table 2.

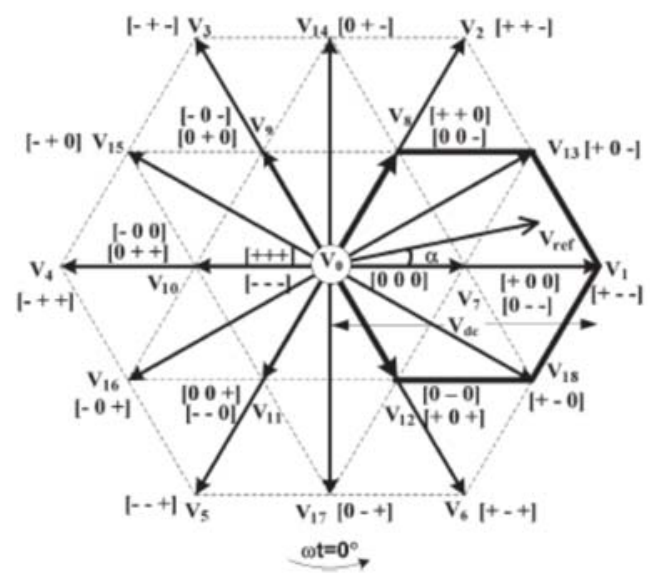

Figure 4. Voltage space vectors and switching states of a coupled inverter.

$$
\begin{aligned}
& H_{i}=1+f i x\left(\operatorname{rem}\left(\frac{\alpha}{60}\right)\right) \\
& V_{R e f, n}=V_{R e f}-V_{7}
\end{aligned}
$$

In space vector PWM, $\mathrm{V}_{\text {Ref }}$ is synthesized by two active and two zero switching times derived by voltage-second balance principle and given in (11), (12) and (13). Here $T_{1}, T_{2}$ are active switching times and $\mathrm{T}_{Z}$ is the zero-switching time. Zero switching time is applied equally at beginning and ending of switching pattern and $T_{s}$ is the sampling period. $V_{\text {Ref }}$ located in sector -1 of $H_{1}$ is synthesized using coupled PWM technique shown in Table 3.

Table 2. Switching states of coupled inverter (Switch ON-1, OFF-0)

\begin{tabular}{ccc}
\hline Coupled Inverter & Inverter-I & Inverter-II \\
\hline+ & 1 & 0 \\
0 & 0 or 1 & 0 or 1 \\
- & 0 & 1 \\
\hline
\end{tabular}

$$
\begin{aligned}
& T_{1}=\frac{V_{r e f}}{0.5 * V_{d c}} \frac{\sin \left(60^{\circ}-\beta\right)}{\sin \left(60^{\circ}\right)} T_{S} \\
& T_{2}=\frac{V_{r e f}}{0.5 * V_{d c}} \frac{\sin (\beta)}{\sin \left(60^{\circ}\right)} T_{S} \\
& T_{Z}=T_{S}-T_{1}-T_{2}
\end{aligned}
$$


Here $T_{1}, T_{2}$ are the switching times of both inverters in $\left[\begin{array}{lll}0 & 0 & 0\end{array}\right],\left[\begin{array}{lll}1 & 0 & 0\end{array}\right]$ and $\left[\begin{array}{lll}1 & 0 & 0\end{array}\right],\left[\begin{array}{lll}1 & 0 & 0\end{array}\right]$ respectively. $\mathrm{T}_{Z} / 2$ is the switching time during starting and ending of each half of the switching cycle in $\left[\begin{array}{llll}1 & 0 & 0\end{array}\right],\left[\begin{array}{lll}1 & 0 & 0\end{array}\right]$ and $\left[\begin{array}{lll}1 & 1 & 0\end{array}\right],\left[\begin{array}{lll}1 & 1 & 1\end{array}\right]$ respectively. Ts is the one half of the switching period.

Table 3. Dwell times of coupled inverter

\begin{tabular}{|c|c|c|c|}
\hline Vector times & $\begin{array}{l}\text { Coupled inverter } \\
\text { Switching states }\end{array}$ & $\begin{array}{c}\text { Inverter-I } \\
\text { Switching states } \\
\end{array}$ & $\begin{array}{c}\text { Inverter-II } \\
\text { Switching states } \\
\end{array}$ \\
\hline $\mathrm{T}_{1}$ & 011 & 000 & 100 \\
\hline $\mathrm{T}_{2}$ & 111 & 100 & 100 \\
\hline$T_{z / 2}$ & 101 & 100 & 110 \\
\hline $\mathrm{T}_{\mathrm{z} / 2}$ & 100 & 100 & 111 \\
\hline
\end{tabular}

\section{RESULTS AND DISCUSSION}

The numerical simulation and theoretical studies of vector controlled open end winding induction motor is carried out in MATLA/simulink. The induction motor stator and rotor resistances are 1.57 $2,1.21 \Omega$ respectively and inductances are $0.17 \mathrm{H}$ and $0.17 \mathrm{H}$. The mutual inductance and moment of inertia are $0.165 \mathrm{H}$ and $0.089 \mathrm{Kg} \cdot \mathrm{m}^{2}$ respectively. Each inverter Dc voltage is $300 \mathrm{~V}$ and effective DC voltage is $600 \mathrm{~V}$. The switching frequency of the inverter is taken as $300 \mathrm{~Hz}$.

The results of decoupled PWM technique based open end winding induction motor drive are presented in Figure 5. The transient behaviour of the drive is shown in Figure (a). Here the voltage plots represent effective pole voltage Vaoa'o', phase voltage Vaa' and CMV of the inverter. The drive characteristics are motor stator currents, speed and torque. The motor reuires high torque during transient. The steady state and loaded behaviour of the drive are represented in Figure 5(b) and 5(c) respectively. Compared to the transient behaviour the constant pulse position is observed in remaining two states but the magnitude of voltage levels and the number of voltage levels are same in all the three conditions. The magnitude of $\mathrm{CMV}$ is $\pm \mathrm{V}_{\mathrm{dc}} / 6(100 \mathrm{~V})$.

The results of space vector coupled PWM fed open end winding induction motor drive are shown in Figure 6. The transient steady state and loaded behaviour of the drive are represented in Figure 6(a),6(b) and 6(c) respectively. Here the magnitude of CMV is $\pm \mathrm{V}_{\mathrm{dc}} / 3(200 \mathrm{~V})$. The CMV of any inverter is the average of effective pole voltages. Comparing the voltage plots of Figure5 and Figure6 decoupled PWM give low CMV than coupled PWM technique. For a set reference speed of 1200 RPM with both the PWM techniques the dual inverter fed open end winding induction motor drive generates three-level pole voltages with a voltage step of $300\left(\mathrm{~V}_{\mathrm{dc}} / 2\right), 0,-300\left(-\mathrm{V}_{\mathrm{dc}} / 2\right)$. Though the magnitudes of pole voltage are same the magnitude of voltage steps created in resultant phase voltage and CMV are different due to change in pulse position. With decoupled PWM technique the voltage steps in resultant phase have the magnitudes of $200\left(\mathrm{~V}_{\mathrm{dc}} / 3\right), 300\left(\mathrm{~V}_{\mathrm{dc}} / 2\right)$ and 400 $\left(2 \mathrm{~V}_{\mathrm{dc}} / 3\right)$ and with coupled PWM techniques the voltage steps have magnitudes of $100\left(\mathrm{~V}_{\mathrm{dc}} / 6\right)$ and $200\left(2 \mathrm{~V}_{\mathrm{dc}} / 6\right)$. From the results of effective phase voltage, it is observed that number voltage steps and magnitude of voltage steps are different with both PWM techniques. With small voltage step and a greater number of voltages steps the voltage plot reaches to near sinusoidal and hence the harmonic content present in the voltage decreases. It is observed that coupled PWM techniques give small voltage step magnitude but with a greater number of voltage steps, the THD plot of resultant phase voltage shown in Figure 6(d) is less when compared with decoupled PWM technique shown in Figure 5(d). With coupled PWM techniques the voltage and current harmonics will be reduced. The decoupled PWM technique give CMV as $\mathrm{V}_{\mathrm{dc}} / 6$ and $-\mathrm{V}_{\mathrm{dc}} / 6$ where as coupled PWM technique gives $\mathrm{V}_{\mathrm{dc}} / 3$ and $-\mathrm{V}_{\mathrm{dc}} / 3 \mathrm{CMV}$. Though the coupled PWM techniques generates small voltage steps in resultant phase voltage but the CMV is high. This high magnitude of CMV lead to bearing motor failure and problems in nearby systems. As the controllers are robust the drive has good transient and steady state performance. Even at load conditions also only small deviation in speed can be observed. During starting and load conditions to provide sufficient electromagnetic torque the drive draws extra stator current which can be observed from the three phase currents plots shown in Figure 5 and Figure6. However decoupled and coupled space vector PWM techniques are superior to the conventional space vector PWM in reducing the THD, switching losses of the inverter and improving the quality of the output voltage compared to[19]. 

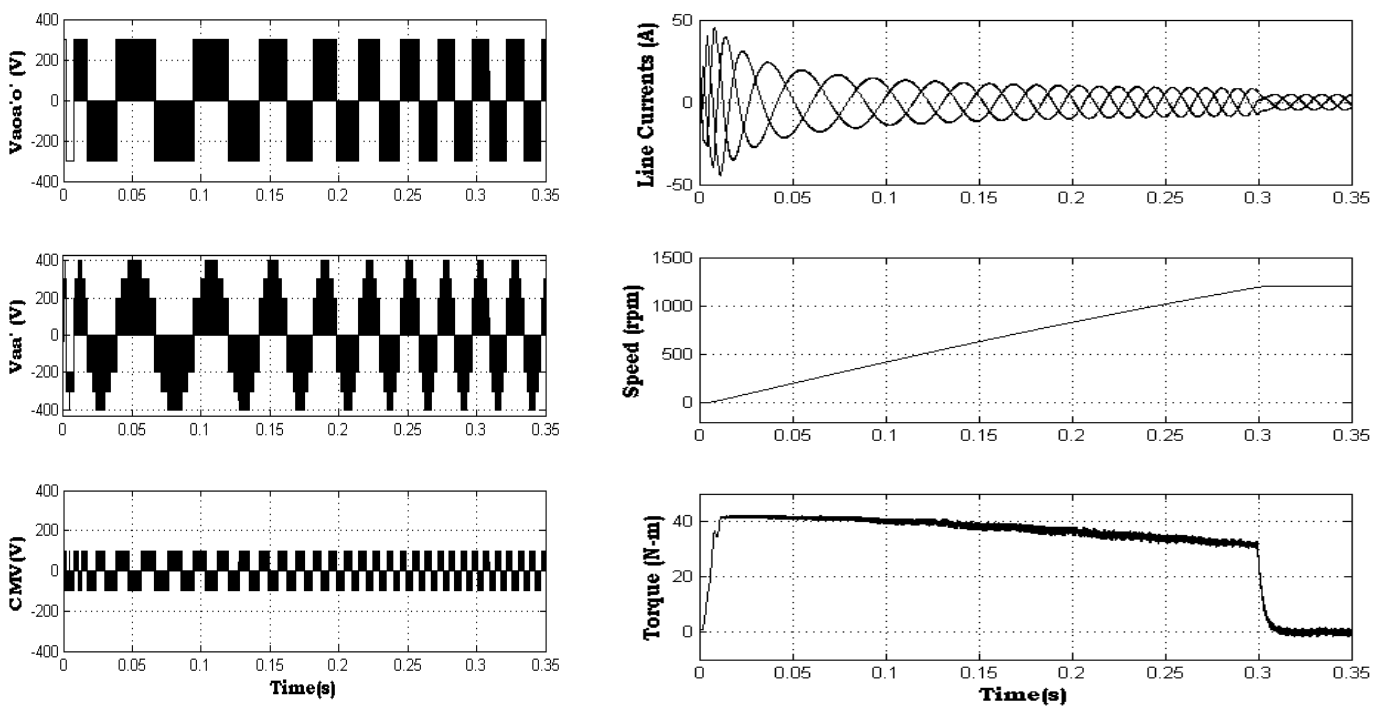

(a)
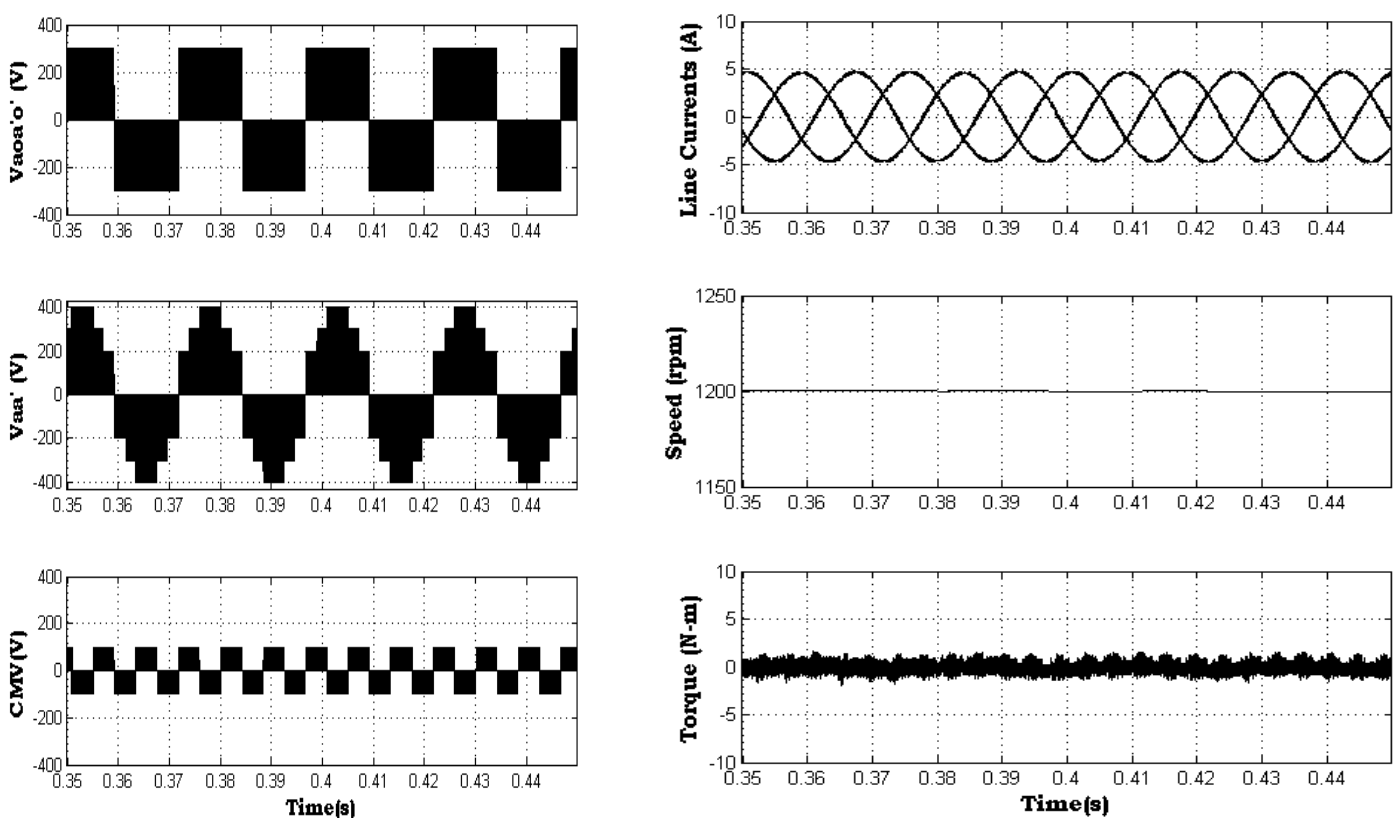

(b) 

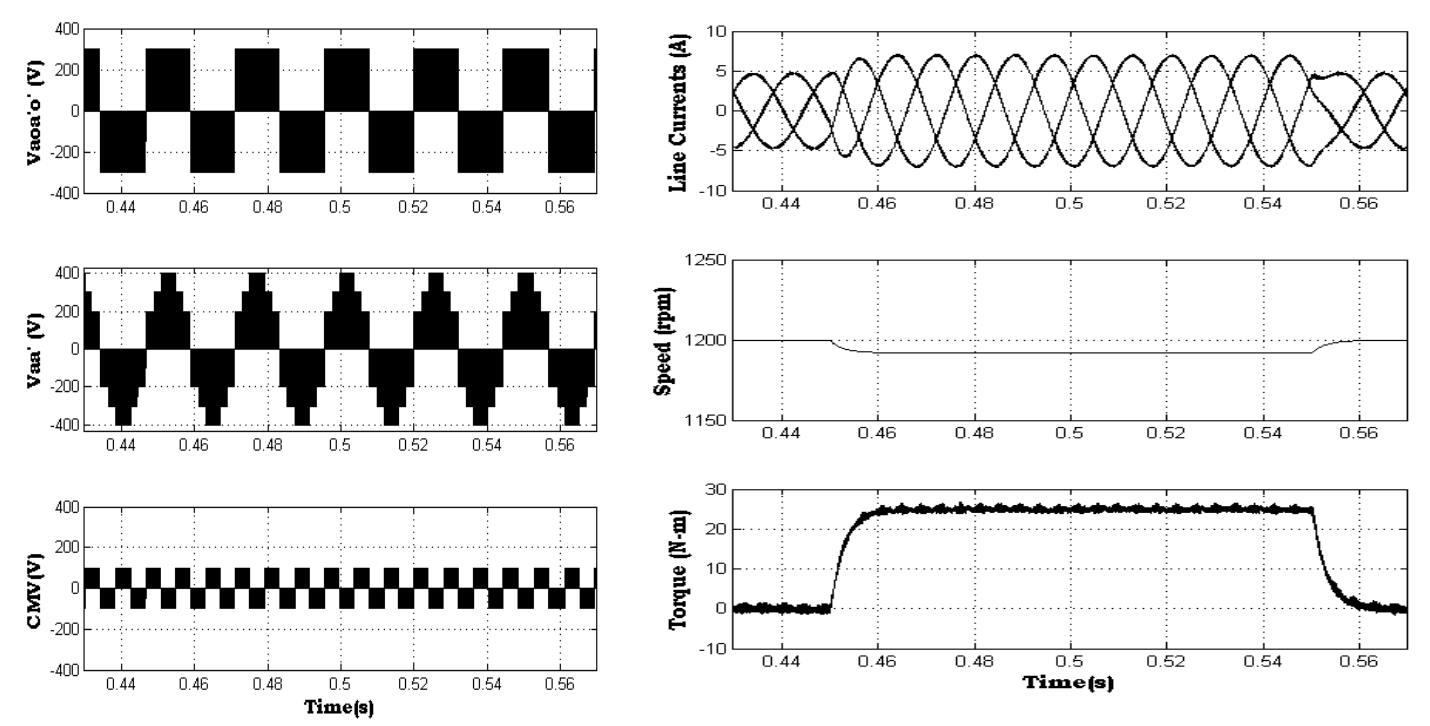

(c)
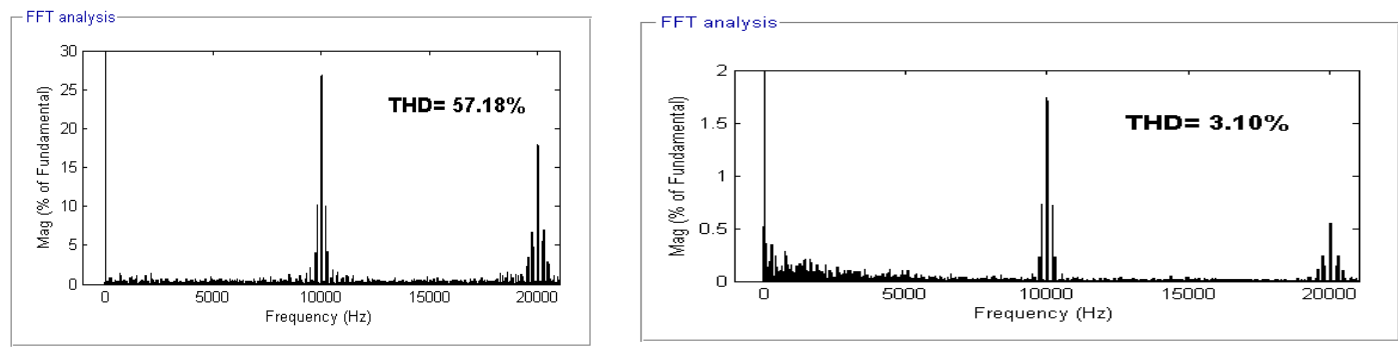

Figure 5. Results of space vector decoupled PWM fed open end winding induction motor drive (a) stating transients (b) Steady state (c) Load conditions (d) voltage THD (e) Current THD
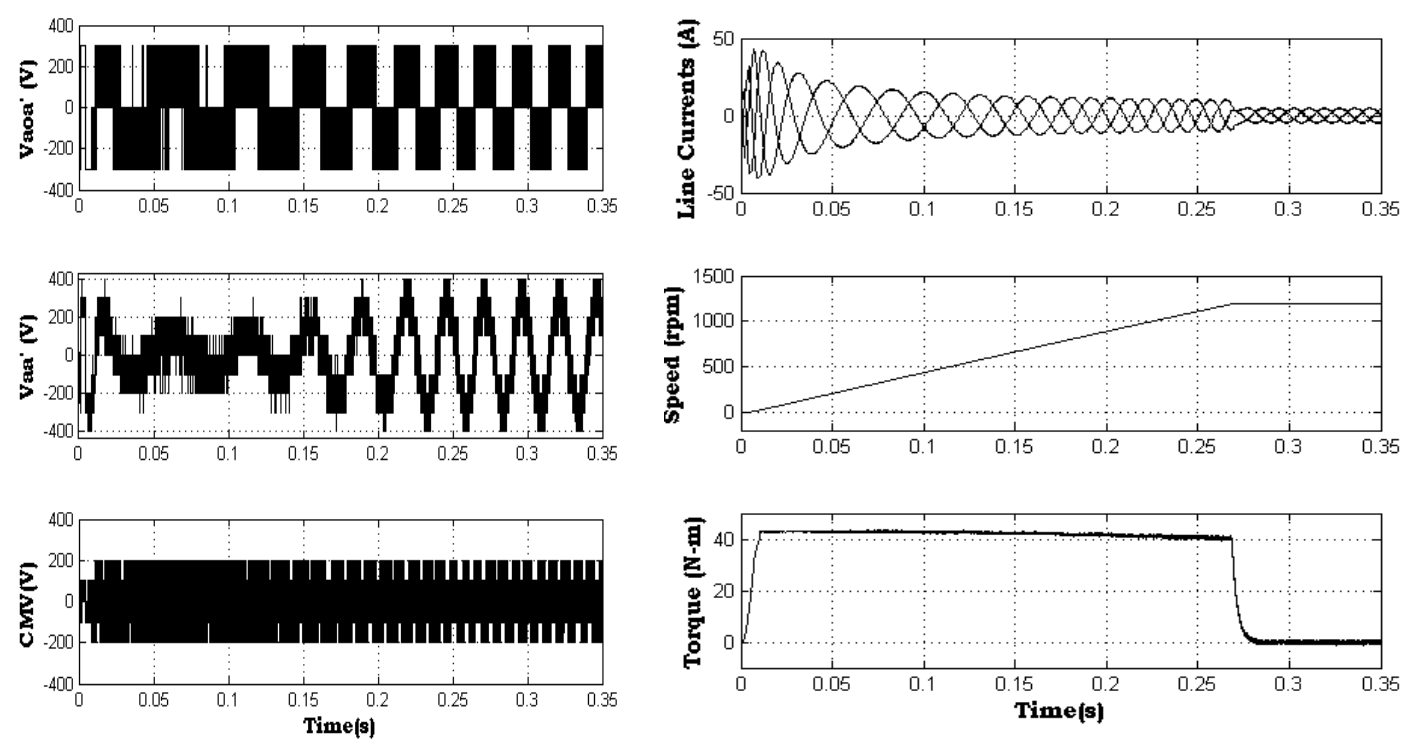

(a) 

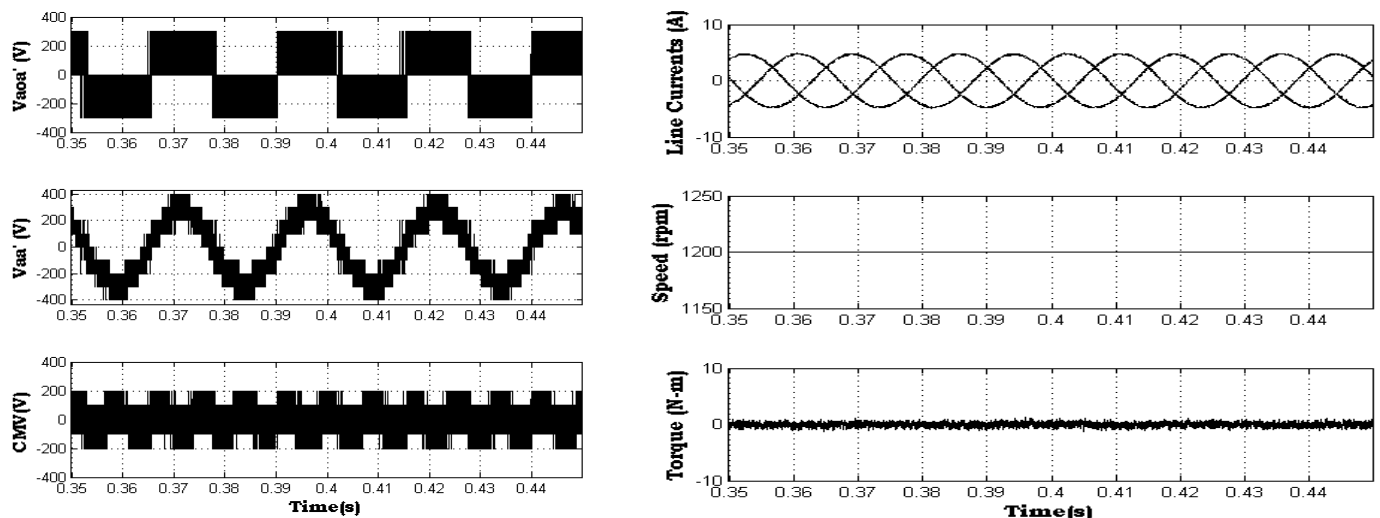

(b)
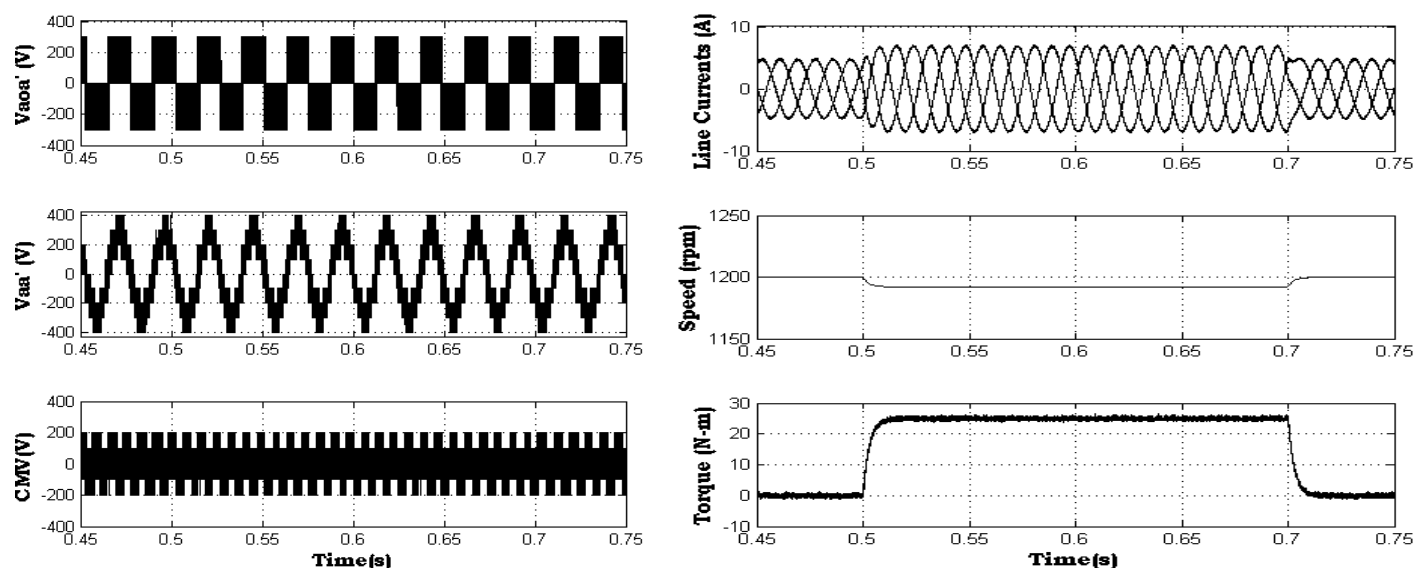

(c)

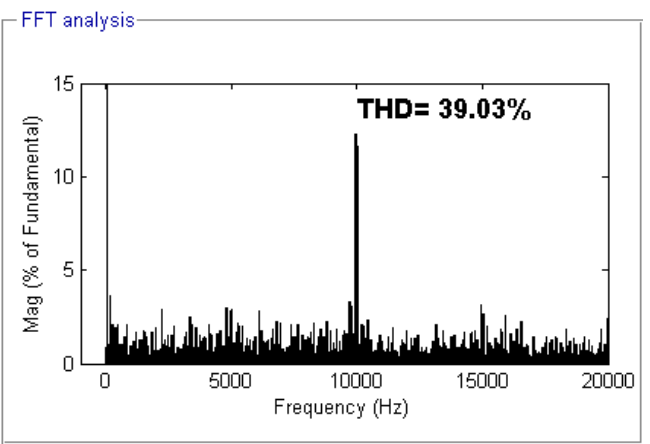

(d)

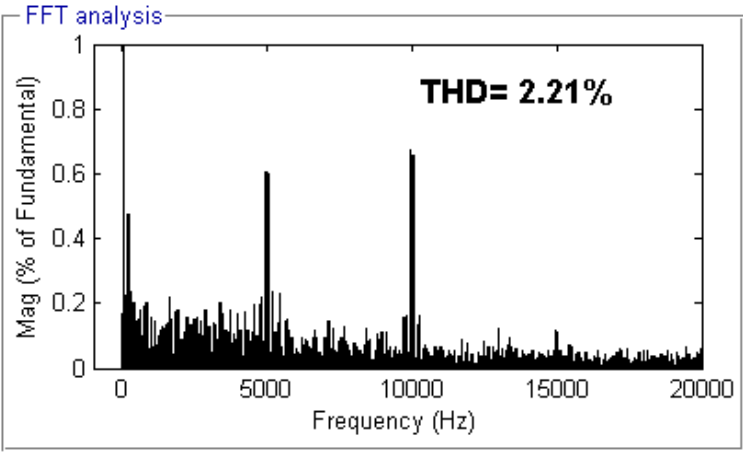

(e)

Figure 6. Results of space vector coupled PWM fed open end winding induction motor drive (a) stating transients (b) Steady state (c) Load conditions (d) voltage THD (e) Current THD

\section{CONCLUSION}

The performance of coupled and decoupled PWM techniques for vector controlled dual inverter fed open end winding induction motor drive is evaluated. It is observed that with coupled PWM techniques quality of output voltage is improved and CMV is high. With decoupled PWM technique quality of output voltage is poor but CMV is small. Hence it can be concluded that for better output voltage coupled PWM technique is preferred and for low CMV decoupled PWM techniques are preferred.

Analysis of coupled and decoupled PWM techniques for induction motor drive (Syed. Munvar Ali) 


\section{REFERENCES}

[1] A. Nabae, I. Takahashi, and H. Akagi, “A new neutral point clamped PWM inverter,” IEEE Trans. Ind. Appl., vol. 17, no. 5, pp. 518-522, 1981.

[2] R. Teodorescu, F. Beaabjerg, J. K. Pedersen, E. Cengelci, S. Sulistijo,B. Woo, and P. Enjeti, "Multilevel converters A survey," in Proc. European Power Electronics Conf. (EPE'99), Lausanne, Switzerland, 1999, CD-ROM.

[3] José Rodríguez, Jih-Sheng Lai, "Multilevel Inverters: A Survey of Topologies, Controls, and Applications," IEEE Trans. Ind. Ele., vol. 49, no. 4, pp 724-737, 2002.

[4] M. Venkatesan, R. Rajeswari, M. Kaliyamoorthy, M. Srithar, "Transient and Steady State Analysis of Modified Three Phase Multilevel Inverter for Photovoltaic System”, International Journal of Power Electronics and Drive System (IJPEDS), vol. 8, no. 1, pp. 31-39, 2017.

[5] J. A. Soo, M. S. Chye, Y. C. Tan, S. L. Ong, J. H. Leong, T. Sutikno, "Non-iterative Wide-modulation-index Switching-angle Calculation Techniques for 15-level Binary Cascaded H-bridge Multilevel Inverter", International Journal of Power Electronics and Drive System (IJPEDS), vol. 8, no. 1, pp.93-99, 2017.

[6] Megat Azahari Chulan, Mohd Junaidi Abdul Aziz, Abdul Halim Mohammed Yatim, Mohd Zaki Daud, "Seven Levels Symmetric H-bridge Multilevel Inverter with Less Number of Switching Devices," International Journal of Power Electronics and Drive System (IJPEDS) vol. 8, no. 1, pp.109-116, 2017.

[7] S. Kouro, M. Malinowski, K. Gopakumar, J. Pou, L. G. Franquelo, B. Wu, J. Rodriguez, M. A. Perez, and J. I. Leon, "Recent advances and industrial applications of multilevel converters," IEEE Trans. Ind. Electron., vol. 57, no. 8, pp. 2553-2580, 2010.

[8] Y. Zhang, Z. Zhao, and J. Zhu, "A hybrid PWMapplied to high-power three-level inverter-fed induction-motor drives," IEEE Trans. Ind.Electron., vol. 58, no. 8, pp. 3409-3420, 2011.

[9] Grain P. Adam, Stephen J. Finney, Ahmed M. Massoud, and Barry W. Williams, "Capacitor Balance Issues of the Diode-Clamped Multilevel Inverter Operated in a Quasi Two-State Mode," IEEE Trans. on Inl. Electronics, vol. 55 , no. $8,2008$.

[10] Stemmler, H., and Guggenbach, P. "Configurations of high-power voltage-source inverter drives," Proc. EPE Conf., Brighton, UK, pp. 7-14, 1993.

[11] V.T. Somasekhar, Srirama Srinivas, and Kommuru Kranti Kumar "Effect of Zero-Vector Placement in a Dual-Inverter Fed Open-End Winding Induction Motor Drive with Alternate Sub-Hexagonal Center PWM Switching Scheme," IEEE Trans. Power Electro., vol. 23, no. 3, pp. 1584-1591, 2008.

[12] W. Leonhard, "30 years of space vectors, 20 years of field orientation, 10 years of digital signal processing with controlled AC-drives, a review (Part1),". EPE Journal, no. 1, pp. 13-20, 1991.

[13] W. Leonhard, "30 years of space vectors, 20 years of field orientation, 10 years of digital signal processing with controlled AC-drives, a review (Part 2)," EPE Journal, no. 2, pp. 89-102, 1991.

[14] B. Venugopal Reddy, Veeramraju Timurala Somasekhar, and Yenduri Kalyan, "Decoupled Space-Vector PWM Strategies for a Four-Level Asymmetrical Open-End Winding Induction Motor Drive with Waveform Symmetries," IEEE Trans. Ind. Electron., vol. 58, no. 11, pp. 5130-5141, 2011.

[15] E.G. Shivakumar, K Gopakumar, S.K. Sinha, AndrePittet, V.T Ranganathan, "Space vector PWM for dual inverter fed open-end winding induction drive," IEEE-APEC-2001, pp. 399-405.

[16] M. Harsha Vardhan Reddy, T. Brahmananda Reddy, B. Ravindranath Reddy, M. Suryakalavati, "Reduction of Common Mode Voltage in Asymmetrical Dual Inverter Configuration Using Discontinuous Modulating Signal Based PWM Technique," Journal of Power Electronics, vol. 15, no. 6, pp. 1524-1532, 2015.

[17] F. Blaschke "The principle of field orientation as applied to the new transvector closed loop control system for rotating-field machines," Siemens Review, pp 217-220, 1972.

[18] M. Harsha Vardhan Reddy, T. Brahmananda Reddy, B. Ravindranath Reddy, M. Suryakalavati, "Random PWM technique for Dual-Inverter-fed Vector-Controlled Induction Motor Drive," Journal of control automation and electrical systems (Springer publisher), vol. 27, no. 1, pp 60-68, 2016.

[19] Syed.munvar ali, V. Vijayya kumar reddy, M. Suryakalavathi, "Simplified active ero state PWM algorithms for vector controlled induction motor drives for reduced common mode voltage," IEEE International conference on recent advances and innovations in engineering (ICRAIE), 2014.

[20] Syed.munvar ali, V. Vijayya kumar reddy, M. Suryakalavathi, "Coupled random PWM technique for dual inverter fed induction motor drive," International Journal of Power Electronics and Drive System (IJPEDS), vol. 10, no. 1, pp. 58-65, 2019.

Indo. J. Elec. Eng. \& Inf, Vol. 7, No. 1, March 2019: 95 - 104 